\title{
GURU DAN BUDAYA HIDUP SEHAT
}

\section{Edwita}

\begin{abstract}
Health is actually a wealth for human life. Health quality is determined by one's health condition and it will affect working productivity. The teacher's healthy life, which can be built up continuously through living in his/her good and healthy environment, will also influence his/her teaching quality. The teacher is expected to become a model and motivate the students and the society to do a healthy life not only physically but also spiritually. To meet this expectation, the teacher should have a perfect healthy life.
\end{abstract}

Kata kunci: Hidup sehat, budaya, pendidikan kesehatan, dan guru

\section{PENDAHULUAN}

Kesadaran masyarakat Indonesia akan pentingnya kesehatan masih rendah. Hal ini ditunjukkan oleh Human Development Index (HDI) Indonesia berada di urutan 112 dari 175 negara di dunia, merupakan gambaran kualitas bangsa Indonesia menurut laporan United Nation Development Program (UNDP) tahun 2002. HDI merupakan standar internasional untuk menentukan kualitas sumber daya manusia suatu negara. Penilaian HDI meliputi; kesehatan, pendapatan dan pendidikan. Adapun masyarakat dengan HDI rendah memiliki ciri-ciri khusus. Diantaranya; sakit-sakitan, kurang cerdas, tidak kreatif, malas dan kurang inovatif (Republika, “Cermin Buram Anak Indonesia” 23 juli 2003). Diakui atau tidak tanda-tanda ini terlihat di masyarakat kita. Angka prevalensi kurang gizi pada anak-anak, ibu hamil dan menyusui masih tinggi. Berbagai penyakit yang diakibatkan oleh tidak peduli akan kebersihan masih muncul berulangkali. Berapa banyak uang yang harus dikeluarkan pemerintah untuk mengatasi penyakit demam berdarah, TBC, muntaber yang muncul silih berganti setiap tahun. Begitu juga masalah pendidikan dasar dan kesenjangan ekonomi masih memiliki kendala.

Usia harapan hidup, pendidikan dan ekonomi, saling terkait dengan status gizi masyarakat yang masih rendah, yang berdampak pada rendahnya kualitas sumberdaya manusia. Bila kondisi ini dibiarkan, bangsa Indonesia akan menghasilkan generasi pekerja kasar yang miskin, tidak mampu memberi makan dan kebutuhan yang layak pada anaknya sehingga siklus terulang lagi, kualitas manusia Indonesia akan lebih buruk.
Menyadari pentingnya arti kesehatan masyarakat dalam pembangunan bangsa ini, pemerintah telah memulai suatu upaya perbaikan kesehatan masyarakat Indonesia. Pada tanggal 1 Maret 1999 telah dicanangkan Gerakan Pembangunan Berwawasan Kesehatan sebagai Strategi Pembangunan Nasional untuk mewujudkan Indonesia Sehat 2010, oleh mantan presiden Habibie (Depkes. 1999). Visi yang akan dicapai adalah masyarakat Indonesia yang penduduknya hidup dalam lingkungan dan perilaku sehat, mampu menjangkau pelayanan kesehatan yang bermutu, adil, dan merata, serta memiliki derajat kesehatan yang setingginya.

Namun, sosialisasi kegiatan ini terlihat lamban. Pembangunan di bidang kesehatan yang merupakan investasi sumber daya manusia (SDM) di masa depan belum menjadikan dunia pendidikan sebagai mitra promosi kesehatan. Pendidikan dan pembudayaan saling terkait. Dalam hal ini " Bagaimana guru-guru bisa dijadikan model dalam berbudaya hidup sehat". Melalui kajian ini diharap pelaku kesehatan dapat memahami guru sebagai model dalam berperilaku sehat, membantu meringan tugas pemerintah. Dimanapun guru berada, budaya hidup sehat guru dapat mempengaruhi lingkungannya, sehingga terbentuk budaya sehat masyarakat. Minimal dimulai dari lingkungan sekolah.

\section{PEMBAHASAN}

\section{Perilaku Hidup Sehat}

Pada masa lampau, pengertian sehat secara sederhana saja yaitu tidak sakit, fisik dalam keadaan baik segenap badan dan bagian-bagiannya atau umumnya dikatakan fisik tidak dalam keadaan sakit. Sekarang, sehat berkaitan dengan berbagai hal, 
sebagaimana yang dinyatakan oleh Eshuys dan kawan-kawan (2001) bahwa sehat itu memiliki beberapa komponen: (1) merasakan fisik dalam keadaan baik (2) merasakan mental dan emosional dalam keadaan baik (3) merasakan sosial dalam keadaan baik (4) merasakan spiritual baik (5) tidak sakit dan tidak terdapat penyakit pada diri seorang. Menurut Organisasi Kesehatan Sedunia (WHO, 1980) sehat adalah keadaan yang sempurna baik fisik, mental, sosial, budaya dan bukan hanya keadaan yang bebas daripada penyakit atau cacat. Sementara Undang-Undang Kesehatan Republik Indonesia Nomor. 23 Tahun 1992, menyatakan bahwa kesehatan atau sehat adalah keadaan sejahtera dari badan , jiwa dan sosial yang memungkinkan setiap orang hidup produktif secara sosial dan ekonomis. Jadi, pengertian sehat menurut Undang-undang lebih luas dan lengkap, yaitu mencakup empat aspek: fisik (badan), mental (jiwa), sosial, dan ekonomi.

Keempat dimensi kesehatan tersebut saling mempengaruhi dalam mewujudkan tingkat kesehatan seseorang, karena perkembangan kesehatan bersifat holistik atau menyeluruh. Wujud dari seseorang yang sehat secara klinis adalah tidak sakit atau organ tubuh berfungsi normal. Sehat secara mental bagi seseorang tercermin dari cara berpikir, cara mengekpresikan emosi dan dari cara mempraktekkan kegiatan keagamaan (spritual). Sehat sosial terwujud dalam cara berhubungan baik dengan orang lain. Sedangkan sehat secara ekonomi terlihat dari produktivitas seseorang dalam arti mempunyai kegiatan yang menghasilkan sesuatu yang dapat memenuhi kebutuhan keluarga secara finansial.

Pengertian sehat yang lebih mengarah pada pendidikan dinyatakan oleh Santrock (1996) bahwa membicarakan masalah kesehatan bukanlah semata menghindari diri dari penyakit, tetapi lebih diutamakan mencapai tujuan-tujuan dari pendidikan kesehatan yang meliputi pembelajaran konsepkonsep, pembentukan sikap dan ketrampilan dalam area pengetahuan gizi, keamanan, kesehatan fisik, mental dan higiene. Pernyataan ini melihat manfaat kesehatan ke depan, dengan merubah paradigma sakit ke paradigma sehat. Selama ini orang lebih mengenal sehat setelah merasakan sakit. Orang perlu belajar dan sadar akan kesehatan dirinya yang didapatkan melalui proses pendidikan kesehatan. Berikutnya perlu dikembangkan pandangan baru kepada para pendidik dan disampaikan pula pada anak didik, yaitu " bermula dari sehat segalanya jadi sejahtera" dan "sehat itu memberi kenikmatan hidup".
Dengan demikian, seseorang dapat dikatakan sehat apabila berada dalam keadaan sempurna fisik, pikiran, perasaan, dan dapat memberikan dampak positif bagi kehidupan pribadi dan sosial di lingkungannya.

\section{Budaya dan Perilaku Hidup Sehat}

Membicarakan budaya hidup sehat merupakan suatu keinginan dan harapan dalam meningkatkan kualitas hidup manusia. Manusia diberikan kelebihan oleh Allah dalam hal akal, pikiran dan perasaan untuk menjadi manusia berbudaya. Budaya sendiri dapat diartikan sebagai himpunan pengalaman yang dipelajari, mengacu pada pola-pola perilaku yang ditularkan secara sosial, yang merupakan kekhususan kelompok sosial tertentu (Keesing,1989).

Manusia berbudaya sehat adalah manusia berkualitas. Yaitu manusia sehat secara utuh dalam arti fisik, psikologis, sosial, dan spritual. Sehat berhubungan dengan sikap dan perilaku. Perilaku sehat ini menurut Becker (2001) adalah perilaku yang berkaitan dengan upaya atau kegiatan seseorang untuk mempertahankan dan meningkatkan kesehatannya. Dan Soekijo (2003) menjelaskan perilaku hidup sehat pada dasarnya adalah suatu respons seseorang terhadap stimulus yang berkaitan dengan sakit dan penyakit, sistem pelayanan kesehatan, makanan, serta lingkungan. Dengan demikian perilaku hidup sehat seseorang terbentuk dari budaya sehat lingkungannya, bagaimana masyarakat dan pemerintah memberikan perhatian yang besar akan pentingnya kesehatan.

Budaya hidup sehat dipengaruhi oleh faktor internal dan eksternal. Menurut hasil penelitian, yang dikutip dari Wallstone \& Wallstone menyatakan bahwa perilaku hidup sehat seseorang dipengaruhi oleh pemahaman sehat didasarkan atas kepercayaan tertentu, kemampuan merasakan nilai-nilai sehat dan menanggapi resiko kesehatan. Di dalam masyarakat ada orang yang percaya bawa sehat dan sakit itu adalah takdir Tuhan, jadi tidak perlu dipermasalahkan. Bagi masyarakat yang berpikir positif tentang sehat, akan berusaha berperilaku sehat dalam setiap aktivitas kehidupannya, dan bagi kelompok ini sehat merupakan tanggung jawab dan hasil dari perilaku sendiri. Sedang mereka yang berpikir resiko kesehatan yaitu sakit, lebih percaya pada tangan dokter atau pihak lain yang dapat membuat mereka sehat, jadi bukan oleh keinginan dalam diri sendiri.

Ada empat faktor yang mempengaruhi perilaku hidup sehat yaitu motivasi, kemampuan, 
persepsi dan kepribadian. Motivasi adalah suatu kekuatan yang mendorong orang berperilaku tertentu, kemampuan menunjukan kapasitas seseorang, persepsi adalah bagaimana seseorang menafsirkan informasi secara seksama, sehingga perilakunya sesuai dengan yang diinginkan, sedangkan kepribadian adalah karakteristik seseorang yang meliputi pengetahuan, sikap, keterampilan dan kemauan. Misalnya, seorang guru yang berperilaku hidup sehat sangat dibutuhkan untuk memberikan contoh tindakan dan memberikan petunjuk kepada anak didiknya untuk berperilaku hidup sehat.

Hidup dalam keadaan sehat adalah harapan manusia secara universal. Nilai sehat melebihi nilai segala sesuatu yang dimiliki manusia. Dalam keadaan sehat orang dapat berbuat banyak dan produktif secara sosial dan ekonomi. Perilaku hidup sehat perlu dibudayakan melalui pembiasaan-pembiasaan. Menurut Becker, perilaku hidup sehat yang perlu dibiasakan adalah: (1) makan dengan menu seimbang (2) olahraga teratur (3) tidak merokok (4) tidak minum minuman keras dan narkoba (5) istirahat cukup (6) mengendalikan stress (7) perilaku atau gaya hidup lain yang positif bagi kesehatan. Hal ini sejalan dengan beberapa program menuju Indonesia Sehat 2010 seperti yang tercantum pada profil kesehatan Indonesia 2001, antara lain tentang perilaku sehat yaitu: (1) perbaikan gizi, mengkonsumsi gizi seimbang. (2) melakukan olahraga teratur (3) tidak merokok (4) memanfaatkan pelayanan kesehatan

Dari uraian di atas, dapat dinyatakan bahwa budaya hidup sehat adalah segala penghayatan dan aktivitas manusia yang berhubungan dengan pembentukan fisik sehat, pikiran sehat, mental sehat, spiritual sehat yang bernilai baik bagi diri dan lingkungan sosialnya. Dan hal utama, manusia tersebut memiliki kesadaran sendiri untuk selalu berupaya meningkatkan kesehatannya.

\section{Pendidikan Kesehatan dan Budaya}

Pendidikan dan budaya memiliki kaitan yang sangat erat. Pendidikan adalah suatu proses pemupukan akal budi dan kebudayaan atau budaya merupakan produk akal budi manusia yang bersemi melalui medium pendidikan. Salah satu produk pendidikan adalah budaya hidup sehat yang didapatkan dari pendidikan kesehatan.

Pendidikan kesehatan, khususnya perilaku hidup sehat dan bersih yang di laksanakan di sekolah merupakan salah satu cara dari lima tingkatan pencegahan (five levels of prevention) dari Leavel and Clark, yaitu sebagai Promosi Kesehatan (Health
Promotion). Kegiatannya antara lain; peningkatan gizi, kebiasaan hidup sehat, sanitasi dan higiene (Soekijo, 2003) Dan Kaufmann (1995) melengkapi tentang pelaksanaannya bahwa pendidikan kesehatan yang baik untuk anak-anak harus di rencanakan sebagai bentuk kerangka terbentuknya perilaku yang sadar akan kesehatannya dan lingkungan. Kegiatan pembelajaran tidak direncanakan perminggu, atau pada hari-hari tertentu saja melainkan menyatu dengan semua aktivitas di sekolah. Dengan demikian pendidikan kesehatan di sekolah pada hakikatnya adalah suatu kegiatan atau usaha untuk menyampaikan pesan kesehatan kepada anak didik dengan harapan dapat memperoleh pengetahuan dan pembiasaan-pembiasaan hidup sehat yang baik. Tegasnya, dengan adanya proses pendidikan kesehatan bagi anak dapat membawa akibat terhadap terbentuknya budaya hidup sehat.

\section{Guru Berbudaya Hidup Sehat}

Sebagai satu bagian integral dari sistem pendidikan, guru adalah sebagai: (1) pekerja profesional berfungsi mendidik, mengajar dan melatih (2) pekerja kemanusiaan dengan fungsi merealisasikan seluruh kemampuan yang dimiliki, serta (3) sebagai petugas kemasyarakatan dengan fungsi mengajar dan mendidik masyarakat untuk menjadi warga negara yang baik.

Dalam melakukan aktivitas mendidik, guru haruslah mengarahkan pembelajaran pada segi-segi pengembangan nilai-nilai atau norma-norma dan penguasaan bidang ajaran secara seimbang, sehingga anak didik dapat berperilaku positif dimanapun berada. Guru bukan hanya bertanggung jawab akan terlaksananya pembelajaran dalam arti pencapaian tingkat pemahaman atau penguasaan ilmu dan teknologi tertentu yang bisa menjadikan anak didik cerdas dan terampil, tetapi juga meningkatkan kualitas manusia, yaitu: manusia yang beriman, bertaqwa, berbudi luhur, berkepribadian dan sehat sejahtera. Guru yang ideal hendaklah mampu sebagai; komunikator, fasilitator, motivator, model, pembina, pendongeng, dan peneliti. Memiliki disiplin yang tinggi, dapat memecahkan masalah, mampu membuat keputusan serta kesimpulan yang tepat dalam melaksanakan tugas sebagai pendidik.

Perlu disadari oleh guru peran utamanya sebagai pemimpin mulia bagi anak didiknya. Ia tidak ubahnya seperti orang tua kedua bagi anak-anak di sekolah, dan mempunyai peranan besar dalam memajukan anak didiknya. Oleh karena itu agar seorang guru dapat sukses dalam tugasnya sebagai

Perspektif Ilmu Pendidikan - Vol. 13 Th. VII April 2006 
pendidik perlu beberapa kemampuan yang harus melekat pada dirinya, seperti yang dinyatakan Muhammad bin Jamil Zainu (2002). Kemampuan tersebut adalah: (1) guru menguasai bidang yang diajarkannya, memiliki inovasi dalam praktek mengajar, cinta terhadap pekerjaan dan anak didiknya, dan mengerahkan segala potensi yang dimilikinya untuk mencapai pendidikan yang baik (2) guru menjadi contoh yang baik dalam perkataan maupun perbuatan, dan hendaklah ia melaksanakan terlebih dahulu apa yang ia perintahkan kepada anak didiknya. (3) memahami posisinya sebagai guru, orang tua yang dengan lemah lembut mengajar anak didiknya, serta mampu berbicara sesuai dengan tingkat pemahaman mereka. (4) guru tunduk pada kebenaran, jujur, dapat memenuhi janji, sabar dan ikhlas dalam melaksanakan perannya.

Seorang guru, disamping memiliki kemampuan akademik, ahli mendidik, dan memiliki akhlak yang baik, ia juga harus dapat dijadikan sebagai figur teladan dalam menerapkan pola hidup sehat bagi anak didiknya. Para guru hendaklah sehat jasmani. sehat rohani, dan sehat sosial. Guru yang memiliki kesehatan yang prima terlihat dari penampilannya yang selalu bersih, rapi, energik, riang gembira, penuh perhatian kepada orang lain, rutin melaksanakan ibadah agamanya, dan dimanapun seorang guru berada selalu membawa kebaikan pada lingkungannya. Guru yang berbudaya hidup sehat menjalani kehidupan sehari-hari secara seimbang dalam berbagai hal.

\section{PENUTUP}

Pemahaman guru tentang kesehatan akan tercerminkan pada pandangannya terhadap pendidikan kesehatan itu sendiri dan perilaku kesehatan yang dijalaninya sehari-hari. Dengan kesadaran akan pentingnya arti kesehatan bagi kehidupan, guru diharapkan ikut mengambil bagian dalam pembudayaan hidup sehat. Kemampuan guru dalam mengintegrasikan perilaku hidup sehat pada setiap kegiatan belajar anak dan keinginan guru untuk selalu memotivasi anak sangat berarti bagi pembangunan manusia masa depan. Berperilaku bersih dan sehat serta dengan kesabaran mengingat-kan anak yang lupa adalah kunci kesadaran perilaku hidup sehat yang dimiliki oleh guru yang berbudaya hidup sehat.

\section{DAFTAR PUSTAKA}

Cornacchia, H. J., Olsen, L. K., \& Nickerson, C. J. (1994). Health in elementary school. St Kouis: Mosby.

Departemen Kesehatan Republik Indonesia. (1999). Indonesia sehat 2010. Jakarta.

Departemen Kesehatan Republik Indonesia. (2002). Profil kesehatan Indonesia 2001. Jakarta.

Department of Educational Wellington. (1980). Health suggestion for health education in primary schools.

Dirjen Pembinaan Pendidikan Tenaga Kependidikan dan Ketenagaan Perguruan Tinggi. (2002). Standar kompetensi guru. Jakarta.

Eshuys, G., \& Lawrence. (1999). Fundamentals of health and education. Sidney: The Jacaranda Press.

Heinich, R., Molenda, M., \& Russel, J. (1990). Introduction media. New York: Macmillan.

Hendrick, J. (1996). The whole chid: developmental education for early years. New Jersey: Prentice Hall.

Keesing, R. M. (1989). Antropologi budaya: suatu persepektif kontemporer. Jakarta: Erlangga.

Kendricks, K., \& Messenger. (1995). Healthy young children.

. Health concepts and behaviour. dari www.psy.standews.ac.uk/handbooks/modules/bs1000/ ps1505L2.pdf

Maryati, S. (2000). Hidup sehat menurut Islam. Jakarta: PT Perca.

Notoatmojo, S. (1997). Ilmu kesehatan masyarakat. Jakarta: Rineka Cipta.

. (2003). Pendidikan dan perilaku kesehatan. Jakarta: Rineka Cipta.

Santrock, J. W. (1996). Child development: Physical development. New York: McGraw Hill.

Zainu, M. (2002). Solusi pendidikan anak masa kini. (Syarif Hade, penterjemah). Jakarta: Mustaqiim.

\section{KETERANGAN PENULIS}

Dra. Edwita, M.Pd, dilahirkan di Bukittinggi tahun 1957. Menyelesaikan pendidikan terakhirnya di program S2 bidang Pendidikan Anak Usia Dini. Saat ini aktif sebagai staf pengajar di Program Studi PGSD FIP UNJ setelah sebelumnya berkecimpung selama beberapa tahun menjadi guru (1980-1990). 